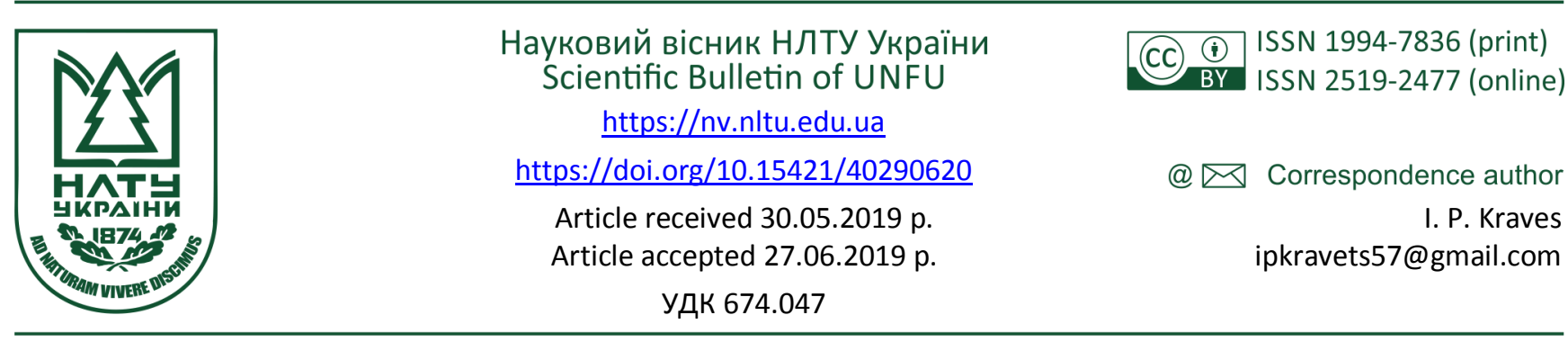

І. П. Кравець

Львівський державний університет безпеки життєдіяльності, м. Львів, Україна

\title{
ДОСЛІДЖЕННЯ ПРОЦЕСУ ПРОПАРЮВАННЯ БУКОВИХ ЗАГОТОВОК І ПИЛОМАТЕРІАЛІВ
}

\begin{abstract}
Зменшити втрати деревини від грибкових пошкоджень під час зберігання і транспортування можна завдяки проведенню теплової стерилізації. Теплову обробку деревини використовують у багатьох деревообробних процесах: виробництво лущеного і струганого шпону, у лісопильному виробництві, процесах гнуття та пресування. Одним із видів теплової обробки деревини $\epsilon$ пропарювання. Відсутність процесу пропарювання букових пиломатеріалів після лісопилення є причиною значних втрат деревини від розтріскування, враження грибами та комахами. У виробничих умовах, під час пропарювання, не враховують багато чинників: особливостей будови деревини бука, її густини, теплових та механічних властивостей. Все це призводить до зайвих втрат матеріалу, теплової енергії та якісних показників букових пиломатеріалів. Тому дуже важливо досліджувати режими та технології пропарювання букових пиломатеріалів із збереженням їх фізико-механічних властивостей. Дослідження проведено з використанням пропарювального ковпака виробничого зразка. Здійснено експериментальні дослідження пропарювання букових заготовок та пиломатеріалів, яке охоплює початковий прогрів, сам процес пропарювання та охолодження. Внаслідок проведення експериментальних досліджень вибрано оптимальні режими пропарювання, які зберігають якісні фізико-механічні показники, такі як: запобігання втратам деревини під час зберігання і транспортування, вирівнювання забарвлення або надання деревині потрібного кольору, покращення міцності та пластичності, прискорення подальшого сушіння.
\end{abstract}

Ключові слова: теплова обробка; штабель; прогрів; охолодження; фізико-механічні показники; оптимальні режими.

Вступ. Деревина та вироби з неї - один з основних видів сировини та товарів народного вжитку. Вона має велике значення в організації побуту, відпочинку та праці. За мірою насичення ринку виробами 3 деревини питання про підвищення іiі якості є невідкладним. Окрім цього, необхідно враховувати, що в умовах розширення міжнародної торгівлі, продукція повинна бути конкурентоспроможною на світовому ринку.

На передових меблевих підприємствах застосовують нове високопродуктивне вітчизняне й імпортне обладнання, постійно вдосконалюються технологічні процеси виробництва меблів.

Здебільшого приріст потужностей на виробництві одержують завдяки технологічному переоснащенню меблевих підприємств напівавтоматичними та автоматичними лініями вітчизняного і зарубіжного виробництва. Реконструкція технологічного обладнання підвищує продуктивність і безпеку праці. Механізація і автоматизація технологічних операцій, ефективна робота пневмотранспорту зменшує пожежну небезпеку.

3 року в рік підвищується технічний рівень місць зберігання деревини на деревообробних підприємствах. Залежно від виду продукції розрізняють склади: пиломатеріалів, круглих лісоматеріалів, балансової деревини, осмолу, дров, щепи і деревного пилу. Великі склади пиломатеріалів займають площу 100 га і більше. 3'явилися автоматичні та напівавтоматичні лінії, впроваджуються нові технологічні процеси, які сприяють покращенню якості продукції (Emelyanov, 2014).

Зменшити втрати деревини від грибкових пошкоджень під час зберігання та транспортування можна завдяки проведенню теплової стерилізації. Теплову обробку деревини використовують у багатьох деревообробних процесах: виробництво лущеного і струганого шпону, у лісопильному виробництві, процесах гнуття та пресування. Одним з видів теплової обробки деревини є пропарювання (Bilej, Kombarov, \& Bilej, 2017). Відсутність процесу пропарювання букових пиломатеріалів після лісопилення $\epsilon$ причиною значних втрат деревини від розтріскування, враження грибами та комахами. У виробничих умовах, під час пропарювання, не враховують багато чинників: особливостей будови деревини бука, iї густини, теплових та механічних властивостей. Все це призводить до зайвих втрат матеріалу, теплової енергії та якісних показників букових пиломатеріалів. Тому дуже важливо досліджувати режими та технології пропарювання букових пиломатеріалів із збереженням їх фізико-механічних властивостей. Таким чином наведене вище свідчить про актуальність дослідження процесу пропарювання букових пиломатеріалів.

\section{Інформація про авторів:}

Кравець Ігор Петрович, канд. техн. наук, доцент, заступник начальника кафедри наглядово-профілактичної діяльності та пожежної автоматики. Email: ipkravets57@gmail.com

Цитування за Дсту: Кравець І. П. Дослідження процесу пропарювання букових заготовок і пиломатеріалів. Науковий вісник НЛТУ України. 2019, т. 29, № 6. С. 98-101.

Citation APA: Kravets, I. P. (2019). The stdy of steaming process of beech workpieces and timber. Scientific Bulletin of UNFU, 29(6), 98101. https://doi.org/10.15421/40290620 
Метою роботи є дослідження режимів процесу пропарювання букових пиломатеріалів із збереженням їх фізико-механічних властивостей.

Викладення основного матеріалу. Дослідження проводили з використанням пропарювального ковпака виробничого зразка, який використовували для перевірки режимів пропарювання, а також для визначення теплоінерційних характеристик пропарювальних установок (Kravets, 2000).

Перша і дуже важлива технологічна операція - формування штабеля. Штабель формують на жорсткій основі (піддоні) із стандартними прокладками. Для штабелів заготовок прокладками є самі заготовки. Пиломатеріали (заготовки) складають суцільними горизонтальними рядами на прокладках. У виробничій практиці стаються випадки, коли пропарюються заготовки пакетами без прокладок, але при цьому значно зростає тривалість пропарювання, а відповідно - енерговитрати, що не можна вважати доцільним.

Габаритний розмір штабеля залежить від внутрішнього об'єму обладнання для пропарювання. Довжина і ширина штабеля за квадратної форми визначається довжиною дошки, за прямокутної форми - основа ширини дорівнює довжині дошки, а довжина - в декілька разів більша. Висота штабеля 5-12 м. Кількість деревини в штабелі 45-55 м³, пожежне навантаження 500700 кг/м². Для провітрювання за висотою штабеля залишають вертикальні канали.

В останні роки на складах пиломатеріалів застосовують пакетний метод зберігання, як найбільш прогресивний, який дає змогу механізувати вантажно-розвантажувальні роботи. Від правильно сформованого штабеля залежить тривалість процесу тепловологооброблення та якість пропарювального матеріалу. Після завантаження штабеля у пристрій впускається пара, тепловий потенціал якої витрачається на прогрів установки, прогрів середовища i, нарешті, прогрів матеріалу (Rokun, 2014).

Після досягнення температури середовища заданого значення, а центральними шарами деревини - відповідної температури, починається процес пропарювання. Витрати пари впродовж процесу теплового оброблення не однакові. За даними досліджень склали таблицю витрат пари під час пропарювання в ковпаку.

Таблиця. Витрати пари на 1 м $^{3}$ деревини в пропарювальному ковпаку

\begin{tabular}{|c|c|c|c|c|}
\hline $\begin{array}{c}\text { Тривалість } \\
\text { процесу, } \tau\end{array}$ & \multicolumn{2}{|c|}{$\begin{array}{c}\text { Витрати пари на } 1 \mathrm{~m}^{3} \\
\text { від початку процесу }\end{array}$} & \multicolumn{2}{|c|}{$\begin{array}{c}\text { Приріст витрат на } \\
1 \mathrm{~m}^{3} \text { за годину }\end{array}$} \\
\hline год & кг & $\%$ & кг & $\%$ \\
\hline 1 & 51 & 59 & 51 & 59 \\
2 & 74 & 86 & 23 & 27 \\
3 & 79 & 92 & 5 & 6 \\
4 & 82 & 95 & 3 & 3 \\
5 & 84 & 98 & 2 & 3 \\
6 & 86 & 100 & 2 & 2 \\
\hline
\end{tabular}

Як видно 3 таблиці, в перші дві години споживається до 86 \% пари, а далі споживання пари залежить від теплоізоляції пропарювального ковпака. Тобто кількість теплоти, яку має пара, що подається, дорівнює тепловтратам через огородження. Для збереження якості пропареної деревини після процесу пропарювання обов'язковим є охолодження матеріалу в установці до температури $t_{2}=0,5 t_{\partial}$.
Обладнання, в якому проводиться пропарювання, повинно мати психрометр та манометр для контролю за станом середовища. Вважаючи, що установка для пропарювання $є$ герметичною, достатньо встановлювати тільки один термометр, який фіксує температуру середовища $-t_{c}$.

Вивантажені $з$ пропарювального пристрою пиломатеріали та заготовки необхідно розміщувати в приміщеннях, закритих від дощу і прямих сонячних променів. Рекомендована тривалість витримки після пропарювання - не менше ніж 10-15 діб. При цьому вологість матеріалу вирівнюється і зменшується до 30-40 \% (залежно від початкової вологості).

Результати дослідження. Під час експериментального дослідження процесу пропарювання вхідними величинами (змінними чиниками) приймали:

- товщину пиломатеріалів та заготовок $\left(S_{1}\right.$, мм), яка може змінюватись у широкому діапазоні (19-100 мм). Найчастіше використовували товщини $S_{1}=32-65$ мм;

- тиск середовища (агента оброблення) - $P$, МПа, якому відповідає визначена температура. Найчастіше використовували діапазон $P=0,05-0,20 \mathrm{MПа;}$

- тривалість оброблення ( $\tau$, год), яка залежить від мети теплової обробки і може тривати $\tau=2-24$ і більше годин.

Вихідними величинами (параметрами оптимізації) приймали:

- динаміку зміни температури середовища і деревини $(t(\tau))$ в різних фазах теплової обробки;

- ступінь впливу процесів теплового оброблення на фізикомеханічні властивості деревини (величина всихання, густина, показники міцності: статична твердість, міцність на стискання поперек волокон).

Таким чином, маючи три основні змінні чинники і зазначені вище функції відгуків (вихідних величин), проводили два двофакторні експерименти, що дає можливість геометричної інтерпретації результатів дослідження.

Перший двофакторний експеримент проводили для визначення швидкості зміни температури деревини залежно від тиску середовища $\mathrm{P}$ i товщини матеріалу $\mathrm{S}_{1}$.

Другий двофакторний експеримент проводили для визначення впливу температури середовища (за тиском P, МПа) та тривалості дії температури (тривалості теплової обробки - $\tau$, год) на фізико-механічні властивості.

Прийнятий розподіл експериментальних досліджень на дві частини $\epsilon$ виправданий ще і тим, що чинник тривалості теплової обробки не має змісту в першому випадку, а чинник товщини відіграє лиш другорядну роль у другому випадку.

Унаслідок статистичної обробки експериментальних даних отримали середнє квадратичне відхилення температури $\sigma_{t}= \pm 1,41^{\circ} \mathrm{C}$. Тобто температурне поле в камері характеризується даними: $t_{c}=\bar{t}_{c} \pm \sigma_{t}$ або $t_{c}=72,7^{ \pm 1,41}{ }^{\circ} \mathrm{C}$. При цьому коефіцієнт варіації становить всього $V_{t}=1,94 \%$, а показник точності $-P_{t}=0,18 \%$. Допустиме значення показника точності для деревооброблення становить $P \leq 5 \%$.

Аналіз результатів експериментальних досліджень свідчать про складність зміни параметрів (температури деревини за об'ємом) у період прогріву та охолодження. Сам процес пропарювання є стабільним у часі і простоpi. Основним показником роботи обладнання для теп- 
лової обробки (як і механічної обробки) $є$ його продуктивність. Продуктивність обладнання позиційного типу визначається за формулою

$$
\Pi=\frac{T}{\tau_{u}} E=n_{u} E,
$$

де: $T$ - тривалість роботи обладнання за певний період: місяць, квартал, рік. Приймають зазвичай рік, тобто $T=T_{p}=335$ діб; $E$ - ємність (кількість матеріалу, який завантажується у пропарювальний пристрій: добуток габариту штабеля на коефіцієнт об'ємного заповнення штабеля).

$$
\begin{aligned}
& E=l_{u m} b_{u m} h_{u m} n_{u m} \beta_{0}=\Gamma \beta_{0}, \\
& \tau_{u}=\tau_{0}+\tau_{n p}+\tau_{o c}+\tau_{o x}+\tau_{36},
\end{aligned}
$$

де: $\tau_{0}-$ тривалість розгону (теплової інерції) обладнання, год; $\tau_{p}-$ тривалість розморожування, год; $\tau_{n p}$ - тривалість початкового прогріву матеріалу, год; $\tau_{o c}-$ тривалість пропарювання (основного процесу), год; $\tau_{o x}-$ тривалість охолодження матеріалу, год; $\tau_{3 в}$ тривалість завантаження та розвантаження установок, год.

Відношення тривалості роботи обладнання $T$ до тривалості циклу теплової обробки $\left(\tau_{u}\right)$ визначає кількість циклів $\left(n_{u}\right)$ роботи обладнання за певний період (зазвичай - рік).

Тривалість розгону (теплової інерції) обладнання залежить від конструкції установки. За виробничими даними, теплова інерційність пропарювальних ковпаків становить (не перевищує) дві години, тобто $\tau_{0}=1,5-2,0$ години. Така ж приблизно тривалість завантаження і розвантаження установки за допомогою кран-балки або тельферної установки.

Тривалість розморожування (знаходили тільки в зимовий період, коли $t_{0}<0{ }^{\circ} \mathrm{C}$ ) визначали за формулою, переведеної на тривалість у годинах

$$
\tau_{p}=\frac{0,69 \mathrm{~S}_{1}^{2}}{\lambda \mathrm{t}_{\mathrm{c}}}\left[\gamma \rho_{y} \frac{W-W_{z p}}{100}+\rho C_{(-)}\left(-t_{0}\right)\right] \cdot 10^{-4} .
$$

Тривалість початкового прогріву матеріалу визначали за формулою із врахуванням поправкового коефіцієнта за температури середовища $\tau_{c}=95-98{ }^{\circ} \mathrm{C}$ (для пропарювальних ковпаків, пропарювальних камер і барабанів), а саме:

$$
\tau_{n p}=0,15 S_{1}^{1,5} \lg W\left(2,4+0,08 S_{1}^{0,7}\right),
$$

де $k=2,4+0,08 S_{1}^{0,7}-$ поправковий коефіцієнт.

Тривалість охолодження після пропарювання приймали однаковим 3 тривалістю початкового прогріву, тобто $\tau_{o x}=\tau_{n p}$. Тривалість охолодження відраховували 3 моменту відключення подачі пари в пропарювальний пристрій.

Тривалість процесу пропарювання в режимах теплової стерилізації приймали постійною: $\tau_{o c}=6$ год. У режимах пропарювання букових пиломатеріалів для зміни кольорової насиченості тривалість процесу залежить від товщини матеріалу $\left(S_{1}\right)$ та вологості $(W, \%)$ деревини (Kravets, Kushnir, \& Shapovalov, 2016). 3 огляду на те, що для насиченості кольору вологість повинна бути понад 40 \%, а далі ступінь насиченості майже не залежить від вологості, то, за даними Н. Делійські (Nikolov,
\& Delisi, 1985), тривалість пропарювання можна апроксимувати залежністю в годинах

$$
\tau_{o c}=0,047 S_{1}^{1,75} .
$$

Таким чином, отримано математичний опис усіх складових циклу теплової обробки деревини бука, основою якого є пропарювання.

До теплоінерційних характеристик обладнання для пропарювання варто віднести тривалість транспортного запізнення $\tau_{0}$ та постійну часу Т. Рівняння, за яким можна описати зміну температури в пропарювальному пристрої, має такий вигляд (у хв):

$$
\theta(\tau)=k_{0} \theta_{n}\left(\tau_{n}-\tau_{0}\right)\left(1-e^{-\frac{\tau-\tau_{0}}{T}}\right),
$$

де: $\theta(\tau)$ - зміна температури у пропарювальному пристрої, ${ }^{\circ} \mathrm{C} ; k_{0} \theta_{n}-$ величина зміни температури $\left(t_{c}-t_{0}\right),{ }^{\circ} \mathrm{C}$; $\tau_{0}$ - величина транспортних запізнень, хв; $\tau$ - тривалість прогріву, хв; $T$ - постійна часу пропарювального пристрою, хв. За результатами дослідження теплоінерційних характеристик пропарювального ковпака отримали таку залежність:

$$
\theta(\tau)=60(\tau-15)\left(1-\operatorname{Exp}\left(-\frac{\tau-15}{100}\right)\right) .
$$

Отже, тривалість розгону для пропарювального ковпака (коли установка набуває температури $\theta(\tau)=0,67 t_{c}$ ) становить близько двох годин (115 хв). Зняття розгінних характеристик (теплової інерції пристрою) має бути обов'язковою операцією під час пускових випробувань пропарювальних камер, що є основою для автоматизації теплової обробки деревини, а саме пропарюванНЯ.

Висновки. Проведено експериментальні дослідження процесу пропарювання букових пиломатеріалів та заготовок, який охоплює початковий прогрів, сам процес пропарювання та охолодження. Внаслідок цих досліджень вибрано оптимальні режими пропарювання, які зберігають якісні фізико-механічні показники, такі як: запобігання втратам деревини під час зберігання та транспортування, вирівнювання забарвлення або надання деревині потрібного кольору, покращення міцності і пластичності, прискорення подальшого сушіння.

\section{Перелік використаних джерел}

Bilej, P. V., Kombarov, A. M., \& Bilej, P. P. (2017). Analiz methods of leadthrough of the initial heating of saw-timbers before drying. Scientific Bulletin of UNFU, 27(1), 168-171.

Emelyanov, V. G. (2014). Bases of derevinoznavstva and forest merchandizing. Kharkiv: A publishing house KHDAU is the name of V. V. Dokuchaeva, 337 p.

Kravets, I. P. (2000). Identification of regularities of process steaming beech saw-timbers. Candidate Dissertation for Engineering Sciences (05.05.07 - Machines for the Forestry Complex). Lviv, $106 \mathrm{p}$.

Kravets, I. P., Kushnir, A. P., \& Shapovalov, O. V. (2016). Selection of optimal regimes of heat treatment, as a preparatory step before ognezashita wood. Scientific Bulletin of UNFU, 26(4), 271-277.

Nikolov, S., \& Delisi, N. (1985). The change of tyrosinase when propellane. Sofia: Technology, $174 \mathrm{p}$.

Rokun, R. O. (2014). Osnovi technologies of steaming-out and drying of firewoods. Scientific Bulletin of UNFU, 24(7), 162-166. [In Ukrainian]. 


\section{THE STDY OF STEAMING PROCESS OF BEECH WORKPIECES AND TIMBER}

Reducing the loss of wood from fungal damage during storage and transportation can be achieved through thermal sterilization. Thermal treatment of wood is used in many woodworking processes such as production of peeled and planed veneers, in a sawing production, and processes of bending and pressing. One of the types of thermal treatment of wood is steaming. The absence of the process of steaming of beech timber after sawmill is the cause of significant wood losses from cracking, fungal and insects damage. In production conditions, during steaming, many factors are not considered. They are as follows: the features of the beech wood structure, its density, thermal and mechanical properties. All this leads to unnecessary losses of the material, thermal energy and quality indicators of beech timber. Therefore, it is very important to study the modes and technologies of steaming beech timber with the preservation of its physical and mechanical properties. The study was carried out using a steaming hubcap of the production specimen. Experimental researches of steaming of beech workpieces and timber, which cover the initial warming, the process of steaming and cooling, are performed. As a result of experimental research, we have obtained the optimal modes of steaming, which maintain qualitative physical and mechanical parameters, such as: preventing wood losses during storage and transportation, levelling the colouring or providing the wood of the desired colour, improving strength and plasticity, and accelerating further drying.

Keywords: thermal treatment; stack; warming up; cooling; physical and mechanical performance; optimal regimes. 